\title{
LOW-P / HIGH-T PRE-ALPINE METAMORPHISM AND MEDIUM-P ALPINE OVERPRINT OF THE PELAGONIAN ZONE DOCUMENTED IN HIGH-ALUMINA METAPELITES FROM THE VERNON MASSIF, WESTERN MACEDONIA, NORTHERN GREECE E. MPOSKOS ${ }^{1}$, D.K. KOSTOPOULOS ${ }^{2}$ \& A. KROHE ${ }^{3}$
}

\section{ABSTRACT}

A low-P / high-T metamorphic event (andalusite-sillimanite series) of pre-Alpine age, identified here for the first time, has affected the metapelitic rocks of the Vernon Massif. P-T conditions of metamorphism in the western part of the Massif are estimated at $\sim 2.5 \mathrm{~kb} / 600-610^{\circ} \mathrm{C}$, while in the northeastern part they are estimated to have exceeded $4.5 \mathrm{~kb} / 640^{\circ} \mathrm{C}$ respectively. Such $\mathrm{P}-\mathrm{T}$ conditions correspond to geothermal gradients of $68^{\circ} \mathrm{C} /$ $\mathrm{km}$ and $40^{\circ} \mathrm{C} / \mathrm{km}$ for the western and the northeastern parts of the Massif respectively. The inferred steep geothermal gradients require transport of heat from deeper to shallower levels within the crust, achieved via magmatic intrusions in a continental magmatic arc setting. Alpine overprinting is characterized by P-T metamorphic conditions of $\sim 6 \mathrm{~kb} /<350^{\circ} \mathrm{C}$ in the western part and $\sim 9 \mathrm{~kb} /<570^{\circ} \mathrm{C}$ in the northeastern part of the Massif respectively.

Low-P / high-T metamorphic rocks, occurring as klippen in the Cyclades and as blocks in the ophiolitic milanges of Crete, are interpreted as remnants of the pre-Alpine Pelagonian nappe similar to those occurring in the Vernon Massif.

KEY WORDS: LP/HT pre-Alpine metamorphism, Alpine overprinting, Pelagonian Zone, Macedonia, Greece.

\section{INTRODUCTION}

The area occupied by what is known as the Pelagonian Zone is composed of several tectonic units. The bottom two units, namely the neritic carbonate unit, now exposed in the form of tectonic windows (OlymposOssa, Rizomata, Krania), and the blueschist unit (Ambelakia) are characterized by Tertiary metamorphism and deformation. By contrast, the overlying Pelagonian nappe displays a more complex tectonometamorphic evolution during pre-Alpine and Alpine times.

The Pelagonian nappe comprises: a)The pre-Alpine crystalline and magmatic rocks of Mts. Voras, Vernon and Pieria-Kamvounia (Kilias and Mountrakis, 1989) as well as those outcropping further to the south (E. Mt. Othris, S. Mt. Pelion, Skiathos Isl., and N. Euboea Isl.), b)The Permo-Triassic volcano-sedimentary and the Triassic-Jurassic carbonates which are non- to only weakly metamorphosed at the western margin and more intensely metamorphosed at the eastern margin of the Pelagonian nappe, c)The ophiolites, characterized by Late Jurassic - Early Cretaceous deformation, and d)The transgressive Creta-ceous limestones that pass upwards into Palaeocene flysch. Strong tectonism during the Early Cretaceous and Tertiary brought about multiple zones of mylonitization and imbrication, and thrusting of the units from east to west.

Granites, orthogneisses and metapelites are predominant amongst the pre-Alpine lithologies. Various dating techniques applied to the granites and orthogneisses invariably yielded Hercynian crystallization ages (e.g., U-Pb on zircon, Mountrakis, 1983, Yarwood and Aftalion, 1976; Rb-Sr on muscovite and biotite, Katerinopoulos et al., 1992; Ar-Ar on muscovite, Lips et al., 1999; whole-rock Rb-Sr, Koroneos, 1991). Pre-Alpine low-P / highT metamorphism of the metapelites at amphibolite facies conditions led to the formation of migmatites. Subsequent metamorphic events during Alpine times, especially that of epidote-amphibolite facies by Early Cretaceous (Yarwood and Dixon, 1977; Mposkos and Perraki, 2001), were accompanied by penetrative deformation

\footnotetext{
1. Technical University of Athens, Section of Geological Sciences, 9 Heroon Polytechniou, GR-15780, Zografou, Athens, Greece. e-mail: mposkos@metal.ntua.gr

2. Aristotle University, School of Geology, Department of Mineralogy, Petrology and Economic Geology, GR-54006, Thessaloniki, Greece. email: mimis@geo.auth.gr

3. University of Muenster, Institute for Mineralogy, Laboratory for Geochronology, Corrensstrasse 24, D-48149, Muenster, Germany.
} 
and almost completely erased the pre-Alpine mineral assemblages and textures, making it difficult to discriminate pre-Alpine from Alpine protoliths in the Pelagonian nappe.

In this paper we present the pre-Alpine and Alpine metamorphic evolution of the Pelagonian nappe as recorded in high-alumina metapelitic rocks of the Vernon Massif in the Florina and Kastoria areas and correlate the Vernon pre-Alpine metapelites with similar rocks occuring as tectonic blocks in Crete and as klippen in the upper tectonic unit of the Cyclades.

\section{GEOLOGICAL BACKGROUND OF THE VERNON CRYSTALLINE MASSIF}

The Vernon crystalline Massif is composed predominantly of orthogneisses with a granitic-granodioritic to monzonitic composition. The age of crystallization of these rocks is ca. $300 \mathrm{Ma}$ (Mountrakis, 1983; Katerinopoulos et al., 1992; Koroneos, 1991). Field observations suggest that the acid plutonites intruded into low-P / high-T metamorphic rocks (andalusite-sillimanite series), typical of magmatic arc settings. Dominant lithologies are two-mica gneisses, andalusite-cordierite schists and gneisses, and sillimanite-biotite gneisses with subordinate amphibolites, quartzites and muscovite pegmatites. Alpine tectonometamorphic episodes transformed the metapelites to phyllites in the western part, and to garnet-chlorite-muscovite and garnet-staurolite schists in the eastern part.

In the areas of Vernon and Askion mountains there are sizeable outcrops of rocks that have been affected only by Alpine tectonometamorphic episodes. Their protoliths probably represent a Permo-Triassic volcanosedimentary sequence including conglomerates, shales, limestones, and acid and basic volcanics. At the W-SW side of the Vernon Massif they display lower greenschist facies metamorphism (this is the 'metaclastics' series' of Kilias and Mountrakis, 1989), whereas over the eastern side of the Massif their metamorphic grade increases and reaches that of epidote-amphibolite facies (this is the 'Klisoura series' of Kilias and Mountrakis, 1989, which according to these authors was metamorphosed in pre-Alpine times).

Occurrences of high-Al metapelites are scattered throughout the Vernon Massif. Figure 1 shows the positions of sampling sites and associated mineral parageneses related to the degree of pre-Alpine and Alpine metamorphism. It can be seen from Fig. 1 that pre-Alpine andalusite-cordierite-biotite-bearing metapelites predominate over to the western side of Mt. Vernon, whereas sillimanite-biotite and garnet-sillimanite-biotitebearing rocks predominate over to the eastern and northeastern side of Mt. Varnous. In between the two areas, andalusite-sillimanite-biotite-cordierite-bearing metapelites are common.

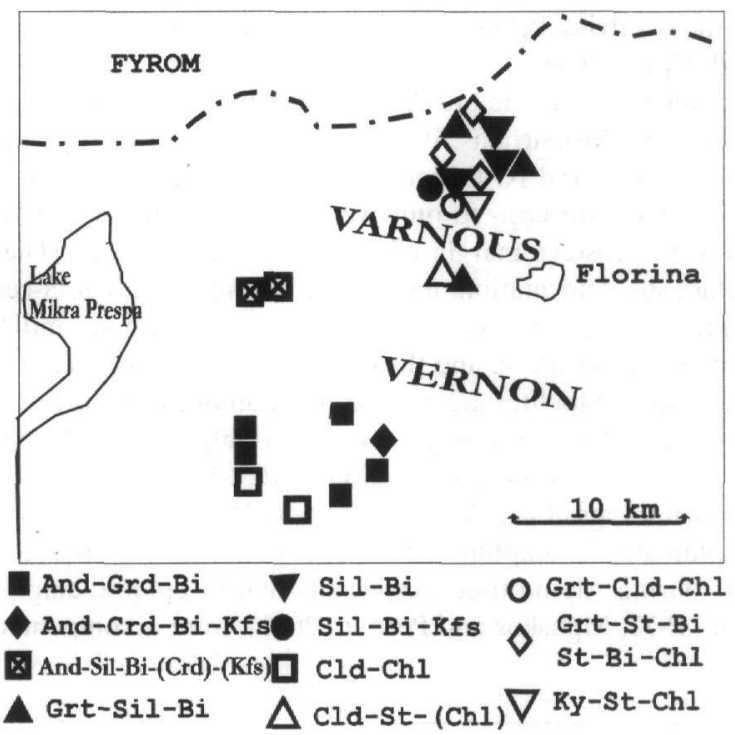

Figure 1:Locations withindex mineral assemblages in metapelites from the Vernon Massif, Florina area, Pelagonian zone. Filled symbols $=$ pre-Alpine assemblages 


\section{PETROGRAPHY - MINERAL CHEMISTRY}

\section{a: Andalusite-cordierite schists and gneisses}

Andalusite-cordierite schists and gneisses are characterized by the mineral assemblage: $\mathrm{And}+\mathrm{Crd}+\mathrm{Bt}+\mathrm{Ms}+\mathrm{Qrz}+\mathrm{Ilm} \pm \mathrm{Pl} \pm \mathrm{Grt}$ (abbreviations after Bucher and Frey, 1994). In addition, K-feldspar and occasionally fibrous sillimanite occur in the andalusite-cordierite gneisses.

Andalusite usually forms idiomorphic to xenomorphic porphyroblasts rich in ilmenite, quartz, biotite, and occasionally, muscovite and K-feldspar inclusions. Andalusite, biotite and quartz aggregates, pseudomorphic after garnet, may also be observed (Fig. 2A). Such a texture is indicative of the reaction: $\mathrm{Grt}+\mathrm{Ms}=\mathrm{And}+\mathrm{Bt}+\mathrm{Qtz}$. In rocks where andalusite coexists with $\mathrm{K}$-feldspar, muscovite is either present in only small amount or it is completely absent. K-feldspar is often perthitic and has been formed via the reaction: $\mathrm{Ms}_{\mathrm{ss}}+\mathrm{Ab}_{\mathrm{ss}}+\mathrm{Qtz}=\mathrm{And}+\mathrm{Kfs}_{\mathrm{ss}}+\mathrm{W}$. Cordierite coexists with andalusite and biotite. It usually forms large poikiloblasts, often elongated parallel to the schistosity planes of the host rock. It is rich in quartz, ilmenite, biotite, muscovite, and to a lesser degree, garnet and andalusite inclusions. Andalusite inclusions in cordierite and muscovite (Fig. 2B) display corroded edges suggesting that cordierite formed at the expense of andalusite according to the reaction: $\mathrm{And}+\mathrm{Bt}+\mathrm{Qtz}=\mathrm{Crd}+\mathrm{Ms}$. Cordierite is rich in Fe with $\mathrm{Mg} \#[\mathrm{Mg} /(\mathrm{Mg}+\mathrm{Fe})]$ ranging between 0.44 and 0.46 (Table 1). Coexisting biotite is also rich in $\mathrm{Fe}$ with $\mathrm{Mg} \#$ ranging between 0.30 and 0.34 (Table 1). Garnet was found as inclusions in cordierite porphyroblasts. It is an MnO-rich almandine with a composition: $\mathrm{Alm}_{63} \mathrm{Grs}_{4} \operatorname{Prp}_{6} \mathrm{Sps}_{27}$.
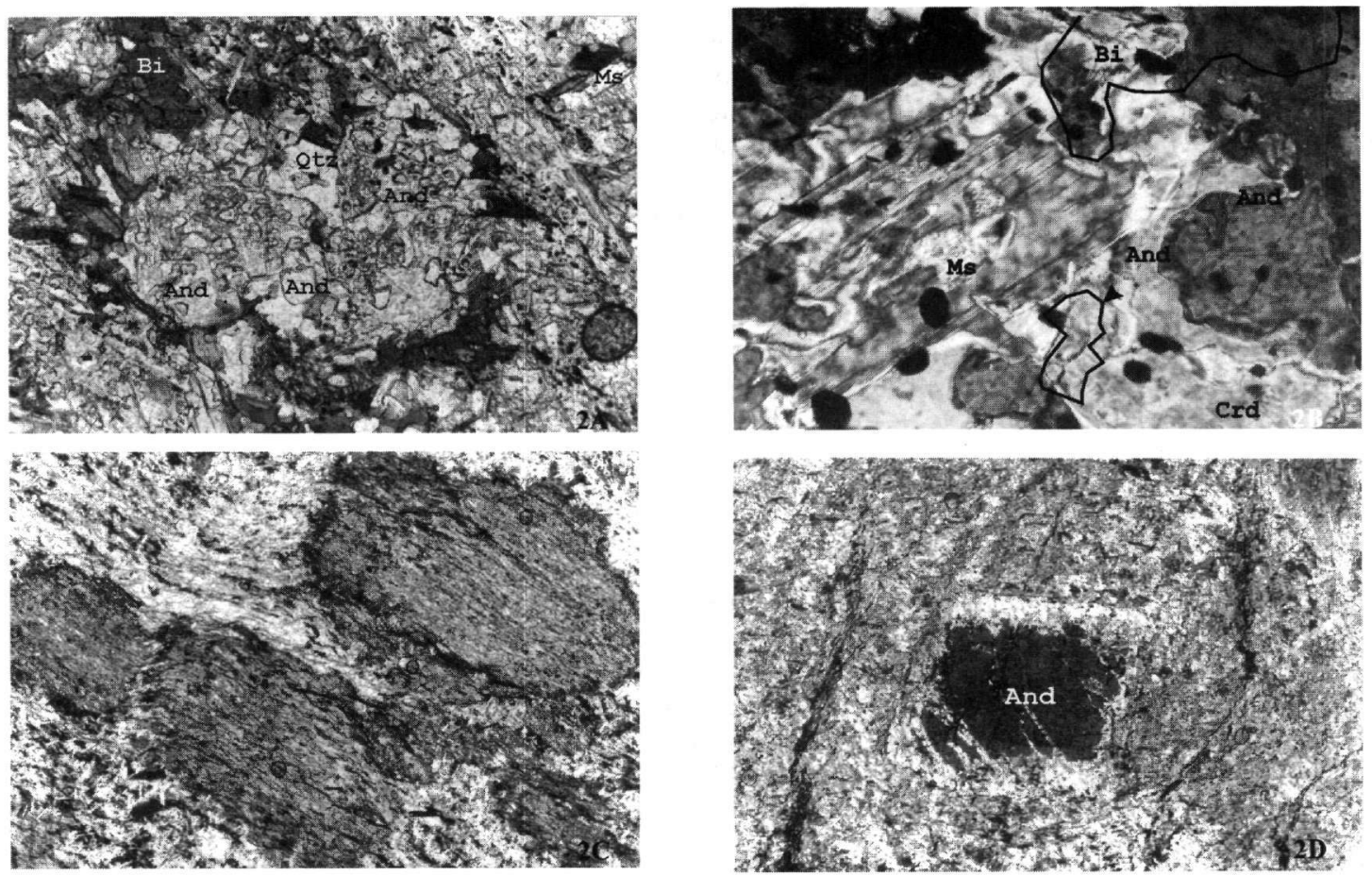

Figure 2: Andalusite - cordierite schists A: Andalusite (And) - biotite (Bt) - quartz assemblage, pseudomorphic after garnet, B: Andalusite (And) and biotite (Bt) with corroded edges, replaced by cordierite (Crd) and muscovite (Ms). The large muscovite flake on the left includes corroded and alusite grains, C:Finegrainedchlorite + muscoviteaggregates, pseudomorphic after cordierite (Crd) inapenetrative lyde formedf ormerandalusite-cordieriteschist,nowcompletelytransformed into phyllite, D: Relict of andalusite (And) in a finegrained matrix of phyllite.The outer part of and alusite is replaced by fine-grained muscovite aggregates.

Figures A,C:polarizeronly;B,D:crossedpolars.Lengthofphotographs: $A, C, D=2,4 \mathrm{~mm}, B=1 \mathrm{~mm}$. 


\section{b: Alpine overprinting}

The extent of Alpine overprinting depends on the degree of deformation. Rocks that escaped Alpine tectonics display only partial or complete replacement of cordierite by fine-grained aggregates of muscovite and chlorite as well as of andalusite by muscovite. By contrast, rocks that underwent penetrative deformation have been completely transformed to phyllites composed of Ms-Chl-Qtz-Ab $\pm \mathrm{Kln} \pm \mathrm{Ctd}$. Microcrystalline aggregates of muscovite or muscovite + chloritoid and of muscovite + chlorite, pseudomorphosed after andalusite and cordierite respectively (Fig. 2C), together with the presence of relictic andalusite (Fig. 2D) and biotite, suggest that the protoliths of the phyllites were andalusite-cordierite schists and gneisses.

\section{c: Andalusite-sillimanite gneisses}

Andalusite-sillimanite gneisses are characterized by the total assemblage: $\mathrm{And}+\mathrm{Sil}+\mathrm{Bt}+\mathrm{Ms}+\mathrm{Kfs}+\mathrm{Pl}+\mathrm{Qtz}+(\mathrm{Crd})+\mathrm{Ilm}$. Andalusite coexists with biotite and quartz in textural equilibrium, pseudomorphically replacing garnet. Sillimanite is the main mineral phase. It is usually oriented parallel to the schistosity planes of the host rock indicating syndeformative growth, or mimics the texture of oriented muscovite flakes at the expense of which it was formed. Sillimanite could have been formed via the following reactions: $\mathrm{Pg}_{\mathrm{ss}}+\mathrm{Qtz}=\mathrm{Sil}+\mathrm{Ab}_{\mathrm{ss}}+\mathrm{Ms}_{\mathrm{ss}}+\mathrm{W}$ and $\mathrm{Ms}_{\mathrm{ss}}+\mathrm{Ab}_{\mathrm{ss}}+\mathrm{Qtz}=\mathrm{Sil}+\mathrm{Kfs}_{\mathrm{ss}}+\mathrm{W}$.

\section{d:Garnet-sillimanite-biotite gneisses and sillimanite-biotite gneisses}

Sillimanite-biotite gneisses are characterized by the total assemblage: $\mathrm{Sil}+\mathrm{Bt}+\mathrm{Ms}+\mathrm{Pl}+\mathrm{Qtz} \pm \mathrm{Grt} \pm \mathrm{Kfs}+\mathrm{Ilm} \pm \mathrm{Py}+\mathrm{Cpy}+\mathrm{Gr}$.

The garnet is an MnO-rich almandine, similar to that occurring in the andalusite-cordierite schists referred to above, with a composition: $\mathrm{Alm}_{66} \mathrm{Grs}_{10} \mathrm{Prp}_{3} \mathrm{Sps}_{21}$ and $\mathrm{Mg} \#^{\prime} 0.13$. The $\mathrm{Mg \#}$ of biotite coexisting with garnet is 0.49-0.51, whereas that of biotite coexisting with sillimanite and K-feldspar is significantly lower (0.35-0.40). Sillimanite shows prismatic or fibrous crystal habits. The former variety often forms crystals up to $1 \mathrm{~cm}$ long (Fig. 3A). Muscovite is the main mineral phase of the plagioclase-bearing sillimanite-biotite gneisses but is present only in subordinate amounts in the K-feldspar-bearing ones. It is relatively rich in $\mathrm{TiO}_{2}$ (range: $0.8-1.63$ wt.\%) and poor in paragonite component $\left(\mathrm{X}_{\mathrm{Pg}}{ }^{\prime 0.12}\right)$. Plagioclase shows an oligoclase composition $\left(\mathrm{X}_{\mathrm{An}}{ }^{\prime} 13\right)$. In those samples where plagioclase coexists with $\mathrm{K}$-feldspar and sillimanite, it displays normal zoning with an albite rim of composition $\mathrm{X}_{\mathrm{An}}{ }^{2}$. The formation of the latter is ascribed to the breakdown of paragonite according to the reaction: $\mathrm{Pg}_{\mathrm{ss}}+\mathrm{Qtz}=\mathrm{Ab}_{\mathrm{ss}}+\mathrm{Ms}_{\mathrm{ss}}+\mathrm{Sil}+\mathrm{L}$. K-feldspar $\left(\mathrm{Or}_{84} \mathrm{Ab}_{16}\right)$ shows perthitic exsolution textures. Its formation is ascribed to the reaction: $\mathrm{Ms}_{\mathrm{ss}}+\mathrm{Ab}_{\mathrm{ss}}+\mathrm{Qtz}=\mathrm{Sil}+\mathrm{Kfs}_{\mathrm{ss}}+\mathrm{L}$ that took place at temperatures higher than that of the paragonite breakdown. Symplectic intergrowths of $\mathrm{Ms}+\mathrm{Ab}+\mathrm{Qtz}$ commonly overgrow K-feldspar. They could have formed by crystallization from a melt produced according to the above-mentioned reaction.

\section{e: Alpine overprinting}

As was the case for the andalusite-cordierite schists and gneisses, rocks not affected by Alpine deformation retained their original pre-Alpine parageneses. Weak Alpine overprinting is attested to by growth of staurolite and new garnet (garnet 2), usually nucleating around pre-Alpine garnet (garnet 1), at the expense of sillimanite and biotite. Rocks that have undergone penetrative deformation have been completely transformed to garnetkyanite-staurolite schists with the total mineral assemblage: $\mathrm{Grt}+\mathrm{Ky}+\mathrm{St}+\mathrm{Bt}+\mathrm{Ms}+\mathrm{Qtz} \pm \mathrm{Pg} \pm \mathrm{Chl} \pm \mathrm{Cld}+\mathrm{Ilm}+\mathrm{Py}$, and to garnet-chloritoid schists with the total assemblage: $\mathrm{Grt}+\mathrm{Cld}+\mathrm{Chl}+\mathrm{Qtz}+\mathrm{Ilm}$. Inclusions of prismatic and fibrous sillimanite and more rarely biotite in Alpine garnet (Fig. 3B) are the only relicts of the pre-Alpine low$\mathrm{P} /$ high-T metamorphism.

Garnet usually forms aggregates of idiomorphic crystals and is rich in ilmenite inclusions. It also contains inclusions of kyanite, chloritoid, staurolite and more rarely chlorite that were all formed during Alpine overprinting. Alpine garnet is almandine-rich with a composition: $\mathrm{Alm}_{73-76} \mathrm{Grs}_{10} \operatorname{Prp}_{11-14} \mathrm{Sps}_{2-3}$, which is different from that of pre-Alpine garnet. It is poorer in spessartine component and richer in almandine and grossular components.

Staurolite and kyanite are the main mineral phases of Alpine overprinting. Kyanite shows kinking and undulatory extinction. Staurolite grew as post- tectonic, non-oriented, idiomorphic prismatic crystals at the expense of kyanite, chloritoid and garnet (Fig. 3C, 3D).

It coexists with one or more of the associations chlorite-kyanite, biotite-chlorite, garnet-chlorite, and garnetbiotite. Staurolite is iron-rich ( $\mathrm{Mg \#} 0.07-0.28)$. The lowest $\mathrm{Mg} \#$ values are shown by staurolites in metapelites west of Florina in central Mt. Varnous, and the highest in eastern Mt. Varnous. 

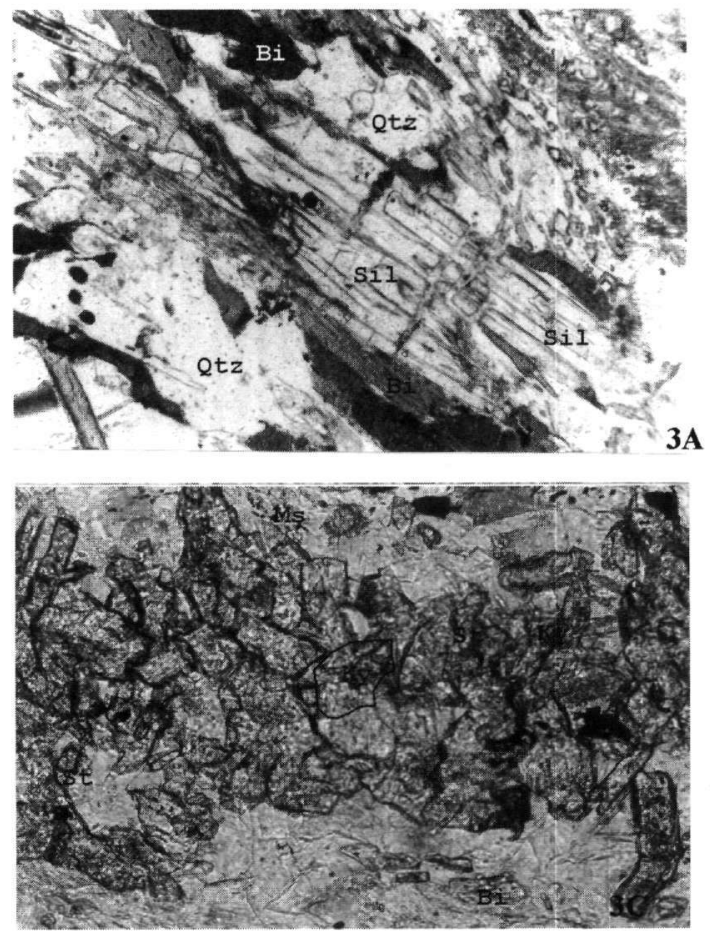
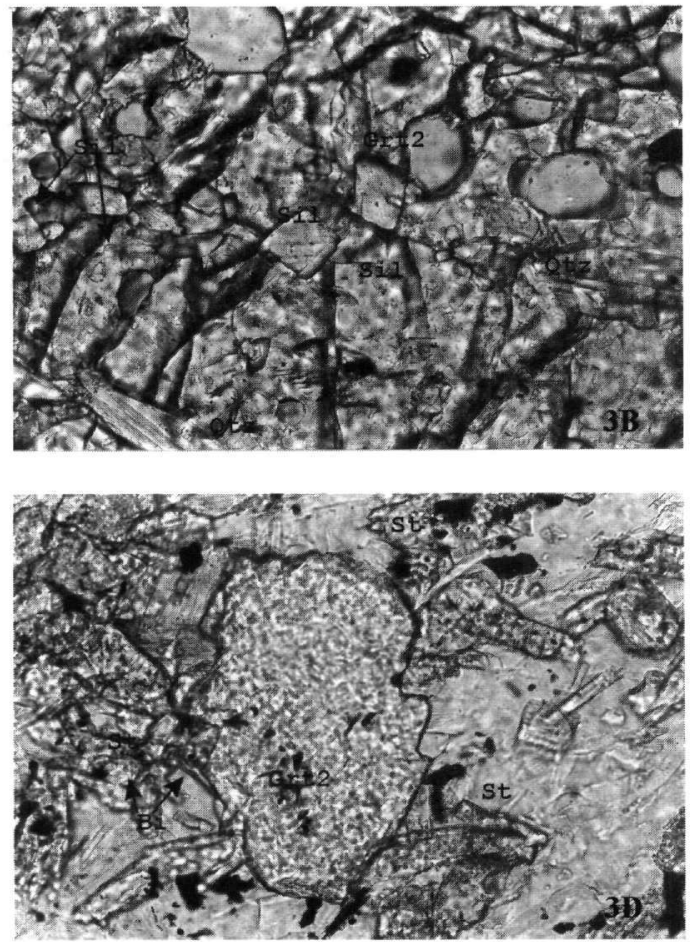

Figure3: SillimanIte-biotitegneissesA:OrientedaggregatesofprismatiC sillimanite(Sil), associatedwithquartz(Qtz)andbiotite(Bt),B:Inclusionsofprismatic sillimanite (Sil) (sections perpendicular to the c axis) in garnet grown during Alpine overprinting, $C$ : Staurolite aggregates (St) replacing kyanite (Ky), D: Alpine garnet (Grt2) with corroded edges overgrown by staurolite aggregates (St) and biotite

(Bt). Polarizer only. Lengths of photographs $A=2,4 \mathrm{~mm}, B=0,6 \mathrm{~mm}, C, D=1,5 \mathrm{~mm}$.

Chloritoid coexists with staurolite in overprinted metapelites from central Mt. Varnous. In the staurolite schists of eastern Mt. Varnous chloritoid occurs only as inclusions in garnet. However, in the same area, chloritoid occurs as a main mineral in the assemblage $\mathrm{Grt}+\mathrm{Cld}+\mathrm{Chl}+\mathrm{Ms}+\mathrm{Qtz}+\mathrm{Ilm}$, thus constraining the peak of metamorphism to have taken place inside its own stability field (see below). $\mathrm{Mg} \#$ values in chloritoid range from 0.17 to 0.33 . Higher values were found for chloritoid inclusions in garnet from garnet-kyanite-staurolite schists from eastern Mt. Varnous (NE Vernon Massif). In general, there is an increase in Mg\# values of chloritoid from SW to NE in the Vernon Massif, and this is concordant with the observed increase of metamorphic grade for the Alpine overprint also from SW to NE. A trend in $\mathrm{Mg} \#$ values similar to that shown by chloritoid is also displayed by staurolite.

As is the case for other minerals, muscovite and biotite exhibit obvious differences in chemical composition between pre-Alpine and Alpine generations. Alpine muscovite is poorer in $\mathrm{TiO}_{2}(0.1-0.6 \mathrm{wt} \%$ ) and richer in $\mathrm{Na}_{2} \mathrm{O}\left(1.5-2.34\right.$ wt. \%; $\left.\mathrm{X}_{\mathrm{Pg}} \sim 0.2-0.3\right)$ in comparison with pre-Alpine muscovite for which it is: $\mathrm{TiO}_{2} \sim 0.8-1.65$ wt. \%, $\mathrm{Na}_{2} \mathrm{O} \sim 0-1$ wt. $\%, \mathrm{X}_{\mathrm{Pg}} \sim 0-0.12$. The formation of Na-rich Alpine muscovite is attributed to the reaction: Als(Sil/ $\mathrm{Ky})+\mathrm{Kf}_{\mathrm{ss}}+\mathrm{Ab}_{\mathrm{ss}}+\mathrm{W}=\mathrm{Ms}_{\mathrm{ss}}+\mathrm{Pg}_{\mathrm{ss}}+\mathrm{Qtz}$, which is corroborated by the presence of coexisting paragonite. Alpine biotite is poorer in $\mathrm{TiO}_{2}(0.9-1.7 \mathrm{wt} . \%)$ and richer in $\mathrm{MgO}(\mathrm{Mg} \#-0.55-0.57)$ in comparison with pre-Alpine biotite for which it is: $\mathrm{TiO}_{2} \sim 2.8-3.5 \mathrm{wt} \%, \mathrm{Mg} \#-0.35-0.51$.

\section{P-T CONDITIONS OF METAMORPHISM}

Pelitic rocks are sensitive to pressure and temperature changes and form minerals that are easy to identify and may be used as indices of metamorphic grade. We have conducted an extensive study of the P-T conditions of both pre-Alpine and Alpine metamorphism of the Vernon Massif metapelites, and the results are depicted in Fig. 4. 


\begin{tabular}{|c|c|c|c|c|c|c|c|c|c|c|c|}
\hline & \multirow{2}{*}{\multicolumn{2}{|c|}{$\begin{array}{l}\text { Andalusite } \\
\text { Crd }\end{array}$}} & \multicolumn{4}{|c|}{ - Cordierite } & \multicolumn{5}{|c|}{$\begin{array}{r}\text { Sillimanite - } \\
\text { Gneiss }\end{array}$} \\
\hline & & & & & Ms & Grt & & & & & Grt \\
\hline & 1 & 2 & 1 & 2 & 1 & 1 & 1 & 2 & 1 & 2 & 1 \\
\hline $\mathrm{SiO}_{2}$ & 47.05 & 48.82 & 33.35 & 34.35 & 44.55 & 35.75 & 43.97 & 43.43 & 37.00 & 34.24 & 37.20 \\
\hline $\mathrm{TiO}_{2}$ & 0.06 & - & 2.40 & 3.40 & 0.97 & - & 1.40 & 1.28 & 2.89 & 3.02 & - \\
\hline $\mathrm{Al}_{2} \mathrm{O}_{3}$ & 33.15 & 33.41 & 20.54 & 19.96 & 36.11 & 20.74 & 37.23 & 37.12 & 19.51 & 18.19 & 20.98 \\
\hline $\mathrm{FeO}_{\text {tot }}$ & 12.01 & 11.31 & 24.30 & 21.97 & 1.23 & 27.78 & 0.86 & 1.11 & 16.56 & 22.59 & 29.44 \\
\hline $\mathrm{MnO}$ & 0.73 & 1.85 & 0.50 & 0.67 & - & 11.71 & - & - & 0.49 & 0.83 & 9.91 \\
\hline $\mathrm{MgO}$ & 5.33 & 5.47 & 5.98 & 6.56 & 0.30 & 1.57 & 0.52 & 0.38 & 8.87 & 6.99 & 1.87 \\
\hline $\mathrm{CaO}$ & 0.15 & - & - & - & - & 1.44 & 0.35 & 0.26 & 0.45 & 0.47 & 0.95 \\
\hline $\mathrm{Na}_{2} \mathrm{O}$ & 0.66 & 0.88 & 0.39 & 0.40 & 0.72 & - & - & 0.60 & - & - & - \\
\hline $\mathrm{K}_{2} \mathrm{O}$ & - & - & 8.15 & 8.22 & 9.74 & - & 10.25 & 10.09 & 9.21 & 9.96 & - \\
\hline Total & 99.14 & 101.74 & 95.57 & 95.53 & 93.62 & 98.99 & 94.58 & 94.30 & 94.98 & 96.29 & 100.35 \\
\hline & (18) & & umber & $\begin{array}{l}\text { of ca } \\
(22)\end{array}$ & ions & oxyg & en at & & & & \\
\hline (12) & & & & & & & & & & & \\
\hline $\mathrm{Si}$ & 4.932 & 4.986 & 5.176 & 5.258 & 6.050 & 2.952 & 5.888 & 5.832 & 5.549 & 5.303 & 3.009 \\
\hline $\mathrm{Ti}$ & - & - & 0.286 & 0.396 & 0.110 & - & 0.141 & 0.129 & 0.326 & 0.352 & - \\
\hline Al & 4.086 & 4.014 & 3.740 & 3.608 & 5.786 & 2.016 & 5.876 & 5.876 & 3.449 & 3.320 & 2.000 \\
\hline $\mathrm{Fe}$ & 1.044 & 0.972 & 3.146 & 2.816 & 0.132 & 1.920 & 0.096 & 0.124 & 2.077 & 2.926 & 1.992 \\
\hline $\mathrm{Mn}$ & 0.072 & 0.162 & 0.066 & 0.088 & - & 0.816 & - & - & 0.062 & 0.109 & 0.679 \\
\hline $\mathrm{Mg}$ & 0.828 & 0.828 & 1.364 & 1.496 & 0.066 & 0.192 & 0.104 & 0.076 & 1.983 & 1.613 & 0.225 \\
\hline $\mathrm{Ca}$ & 0.018 & - & - & - & - & 0.132 & 0.050 & 0.037 & 0.072 & 0.078 & 0.082 \\
\hline $\mathrm{Na}$ & 0.126 & 0.180 & 0.110 & 0.110 & 0.198 & - & - & 0.160 & - & $-\cdot$ & - \\
\hline K & - & - & 1.601 & 1.606 & 1.694 & - & 1.751 & 1.730 & 1.762 & 1.968 & - \\
\hline $\mathrm{Mg} /(\mathrm{Mg}+\mathrm{Fe})$ & 0.44 & 0.46 & 0.30 & 0.35 & & 0.09 & & & 0.49 & 0.35 & 0.10 \\
\hline
\end{tabular}

a: Pre-Alpine metamorphism

Table 2: Representative compositions of alpine minerals in high-alumina metapelites from Vernon Massif.

\begin{tabular}{|c|c|c|c|c|c|c|c|c|c|c|c|}
\hline & \multirow{2}{*}{$\frac{\text { Grt }}{1}$} & \multicolumn{2}{|c|}{ Ctd } & \multicolumn{2}{|c|}{ St } & ChI & \multicolumn{2}{|c|}{ Ms } & \multirow{2}{*}{$\frac{\mathrm{Pg}}{1}$} & \multicolumn{2}{|c|}{$\mathrm{Bi}$} \\
\hline & & 1 & 2 (i) & 1 (i) & 2 & 1 & 1 & 2 & & 1 & 2 \\
\hline $\mathrm{SiO}_{2}$ & 37.24 & 24.50 & 24.80 & 27.71 & 27.73 & 24.27 & 44.23 & 45.22 & 45.56 & 37.05 & 36.51 \\
\hline $\mathrm{TiO}_{2}$ & - & - & - & 0.36 & 0.47 & - & 0.33 & 0.26 & - & 1.31 & 1.44 \\
\hline $\mathrm{Al}_{2} \mathrm{O}_{3}$ & 21.93 & 41.57 & 42.29 & 54.48 & 54.53 & 22.47 & 37.35 & 37.71 & 39.90 & 17.67 & 18.64 \\
\hline $\mathrm{FeO}_{\text {tot }}$ & 34.10 & 23.88 & 19.71 & 13.43 & 12.60 & 17.48 & 1.52 & 1.10 & 0.39 & 17.40 & 16.77 \\
\hline $\mathrm{MnO}$ & 0.97 & - & 0.49 & 0.24 & 0.27 & 0.28 & - & . - & - & 0.36 & - \\
\hline $\mathrm{MgO}$ & 3.10 & 3.22 & 5.41 & 2.36 & 2.79 & 19.68 & 0.50 & 0.66 & - & 12.95 & 11.58 \\
\hline $\mathrm{CaO}$ & 3.65 & - & - & - & - & - & - & 0.35 & 1.01 & - & 0.21 \\
\hline $\mathrm{Na}_{2} \mathrm{O}$ & - & - & - & - & - & - & 2.11 & 1.85 & 6.84 & - & - \\
\hline $\mathrm{K}_{2} \mathrm{O}$ & - & - & - & - & - & - & 8.55 & 8.93 & 1.09 & 9.46 & 8.49 \\
\hline Total & 100.99 & 93.17 & 92.70 & 98.60 & 98.40 & 84.18 & 94.60 & 96.10 & 94.80 & 96.20 & 93.64 \\
\hline & (12) & & $\begin{array}{l}\text { Number } \\
(24)\end{array}$ & of ca & $\begin{array}{c}\text { ions / } \\
(47)\end{array}$ & oxyge & ator & & & (22) & \\
\hline $\mathrm{Si}$ & 2.957 & 3.993 & 3.986 & 7.787 & 7.780 & 5.130 & 5.915 & 5.947 & 5.882 & 5.526 & 5.536 \\
\hline $\mathrm{Ti}$ & - & - & - & 0.077 & 0.099 & - & 0.034 & 0.025 & - & 0.147 & 0.164 \\
\hline Al & 2.052 & 7.985 & 8.011 & 18.044 & 18.032 & 5.598 & 5.886 & 5.845 & 6.071 & 3.105 & 3.331 \\
\hline $\mathrm{Fe}$ & 2.264 & 3.255 & 2.649 & 3.157 & 2.956 & 3.090 & 0.169 & 0.121 & 0.041 & 2.17 .0 & 2.127 \\
\hline $\mathrm{Mn}$ & 0.065 & - & 0.066 & 0.058 & 0.065 & 0.050 & - & - & - & 0.046 & - \\
\hline $\mathrm{Mg}$ & 0.366 & 0.782 & 1.296 & 0.989 & 1.168 & 6.201 & 0.099 & 0.129 & - & 2.879 & 2.618 \\
\hline $\mathrm{Ca}$ & 0.310 & - & - & - & - & - & - & 0.05 & 0.140 & - & 0.034 \\
\hline $\mathrm{Na}$ & - & - & - & - & - & - & 0.546 & 0.472 & 1.714 & - & - \\
\hline K & - & - & - & - & - & - & 1.459 & 1.498 & 0.180 & 1.799 & 1.642 \\
\hline $\mathrm{Mg} /(\mathrm{Mg}+\mathrm{Fe})$ & 0.14 & 0.18 & 0.33 & 0.24 & 0.28 & 0.67 & & & & 0.57 & 0.55 \\
\hline
\end{tabular}


The presence of the assemblage andalusite + cordierite + biotite, which is widespread on the western side of the Vernon Massif, is evidence of low-P metamorphism at temperatures exceeding those required for the stable coexistence of chlorite + muscovite (Fig. 4, curve 8). The high temperature limit of metamorphism lies between curves $10(\mathrm{Ms}+\mathrm{Qtz}=\mathrm{Als}[\mathrm{And} / \mathrm{Sil}]+\mathrm{Kfs}+\mathrm{W})$ and $12\left(\mathrm{Ms}_{\mathrm{ss}}+\mathrm{Ab}_{\mathrm{ss}}+\mathrm{Qtz}=\mathrm{And}+\mathrm{Kf}_{\mathrm{ss}}+\mathrm{W}\right)$ in Fig. 4 because of the assemblage And $+\mathrm{Kfs}+\mathrm{Pl}+\mathrm{Ms}+\mathrm{Qtz}$. This, in conjunction with the presence in certain samples of fibrous sillimanite next to andalusite, further constrains the pressure of metamorphism to about $2.5 \mathrm{~kb}$ (corresponding to $9 \mathrm{~km}$ depth), and maximum temperatures between 600 and $610^{\circ} \mathrm{C}$ assuming unity water activity.

In the NE part of the Vernon Massif sillimanite is the only aluminosilicate phase present. Main mineral associations are: $\mathrm{Grt}+\mathrm{Sil}+\mathrm{Bt}+\mathrm{Pl}+\mathrm{Qtz}$ and $\mathrm{Bt}+\mathrm{Sil}+\mathrm{Pl}+\mathrm{Ms}+\mathrm{Qtz}$, whereas in certain samples $\mathrm{Kfs}$ occurs as an additional phase.

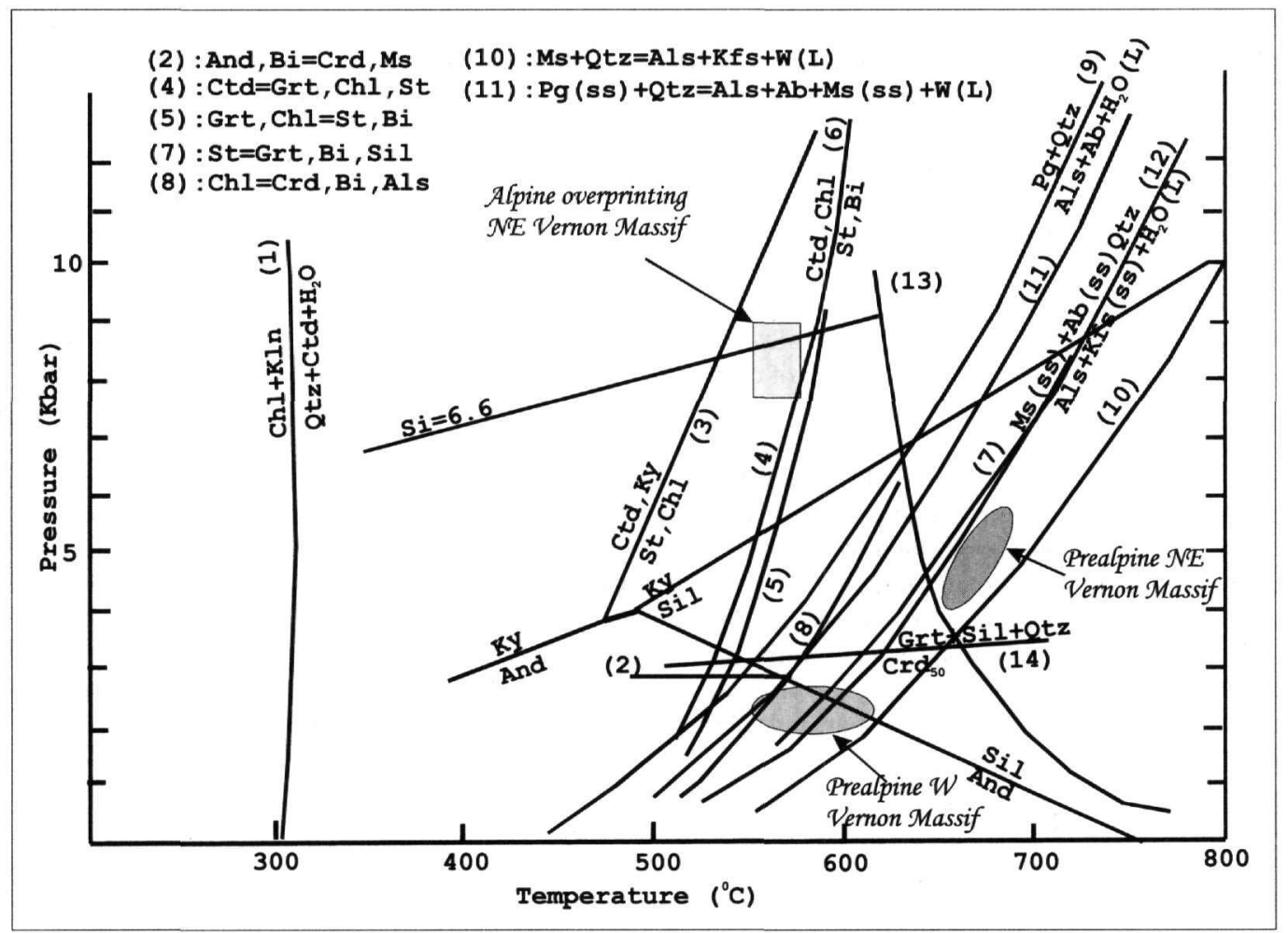

Figure4 :P-Tdiagram with reaction curves in a peliticsystem, taken from Spear (1995). Reaction curve 13 is wetmeltin gofgranite. Isopleth:Si=6.6is from Massonne and Schreyer (1987). Reaction curves 2 and 14 are calculated with theTWEEQU software (Berman,1991)using analyzed mineral compositions. Filled areas indicateP-Tconditions forthepre-AlpineLP/HTmetamorphism and theAlpinemedium-Poverprinting in the Vernon Massifof the Pelagonian zone.

The presence of $\mathrm{Grt}+\mathrm{Sil}+\mathrm{Bt}$ implies that metamorphic conditions overstepped the staurolite maximum stability limit shown by curve 7 in Fig. 4. Curve 7 is nearly identical to curve 12 (Fig. 4), representing the reaction: $\mathrm{Ms}_{\mathrm{ss}}+\mathrm{Ab}_{\mathrm{ss}}+\mathrm{Qtz}=\mathrm{Sil}+\mathrm{Kf}_{\mathrm{ss}}+\mathrm{W}$ (or $\mathrm{L}$ ). The stable coexistence of sillimanite with $\mathrm{K}$-feldspar in metapelites from the NE Vernon Massif suggests that the afore-mentioned reaction took place in the rocks. The presence of migmatites and muscovite pegmatites in the metapelites constrains minimum pressures to $3.5 \mathrm{kbar}$ as indicated by the intersection of curves 10 and 13 in Fig. 4 . The absence of cordierite from the metapelites constitutes additional evidence, since metamorphic pressures in this area must have been higher than those determined by the reaction: $\mathrm{Grt}+\mathrm{Sil}+\mathrm{Qtz}=\mathrm{Crd}$ (Fig. 4, curve 14), which intersects curves 12 and 13 at pressures of 3.2 and 3.5 $\mathrm{kb}$ respectively. The stable coexistence of $\mathrm{Ms}+\mathrm{Qtz}$ limits maximum temperatures to values lower than those determined by the reaction $\mathrm{Ms}+\mathrm{Qtz}=\mathrm{Sil}+\mathrm{Kfs}+\mathrm{L}$, which for $\mathrm{P} \sim 3.5 \mathrm{~kb}$ yields $\mathrm{T}_{\text {max. }}<650^{\circ} \mathrm{C}$. Assuming that the 
reaction: $\mathrm{Ms}_{\mathrm{ss}}+\mathrm{Ab}_{\mathrm{ss}}+\mathrm{Qtz}=\mathrm{Als}+\mathrm{Kf}_{\mathrm{ss}}+\mathrm{L}$ was responsible for melt formation, minimum $\mathrm{P}-\mathrm{T}$ values of $4.5 \mathrm{~kb}$ and $640^{\circ} \mathrm{C}$ respectively are suggested from the intersection of curves 12 and 13 (Fig. 4).

The P-T conditions inferred above for the pre-Alpine metamorphism of the Vernon Massif define a geothermal gradient of $68^{\circ} \mathrm{C} / \mathrm{km}$ for the western side and $40^{\circ} \mathrm{C} / \mathrm{km}$ for the northeastern side of the Vernon Massif respectively. Steep geothermal gradients within continental crust like the gradient found for the western side of the Vernon Massif may only be achieved by transport of heat from the deeper to the shallower levels of the crust via magmatic intrusions that cause thermal metamorphic phenomena.

\section{b: Alpine metamorphism}

On the western side of the Vernon Massif, those andalusite-cordierite schists that experienced penetrative deformation were transformed to phyllites characterized by the total assemblage: $\mathrm{Ms}+\mathrm{Chl}+\mathrm{Qtz} \pm \mathrm{Ctd} \pm \mathrm{Kln}$. Formation of chloritoid constrains minimum metamorphic temperatures to about $300^{\circ} \mathrm{C}$ as suggested by the reaction: $\mathrm{Kln}+\mathrm{Chl}=\mathrm{Cld}+\mathrm{Qtz}+\mathrm{W}$ (fig. 4, curve 1). Moreover, the presence of phengite with $\mathrm{Si}=6.8$ atoms p.f.u. in the underlying Kastoria orthogneiss constrains minimum pressures to around $7 \mathrm{~kb}$ for an assumed temperature of $350^{\circ} \mathrm{C}$.

In the Vernon Massif, the degree of Alpine metamorphism increases progressively from $\mathrm{W}$ to NE where it reaches epidote-amphibolite or even lower amphibolite facies conditions. Grt-Chl and Grt-Chl-Bt assemblages dominate in metapelites with normal Al content, whereas Grt-Cld-Chl, Grt-Chl-St, Ky-St-Chl, Ky-St-Bt and Grt-St-Bt assemblages dominate in Al-rich metapelites. Several lines of evidence suggest that a series of prograde reactions took place starting from the field of stable coexistence of Cld-Ky-Chl (left-hand side of curve 3; Fig. 4) and terminating in that of St-Bt-Chl or Grt-St-Bt (right-hand side of curves 5 and 6, Fig. 4) within the stability field of kyanite. These are: i) The presence of chloritoid, chlorite, kyanite and staurolite inclusions in garnet, ii) the growth of staurolite at the expense of kyanite, and iii) the presence of assemblages such as St-Chl-Bt and Grt-St-Bt. The associations St-Ky-Chl and Grt-Cld-Chl constrain metamorphic temperatures to between values defined by curves $3(\mathrm{Cld}+\mathrm{Ky}=\mathrm{St}+\mathrm{Chl})$ and $4(\mathrm{Cld}=\mathrm{Grt}+\mathrm{Chl}+\mathrm{St})$, i.e. between 530 and $580^{\circ} \mathrm{C}$ assuming $\mathrm{P}=8$ $\mathrm{kb}$ and $\alpha_{\mathrm{H} 2 \mathrm{O}}=1$. It should, however, be noted that the assemblage St-Bt-Chl, which is quite common in metapelites from the NE part of the Vernon Massif, is stable at $\mathrm{T}>580^{\circ} \mathrm{C}$ for $\alpha_{\mathrm{H} 2 \mathrm{O}}=1$. Most of these samples contain pyrite as an additional phase and their biotites contain $0.5 \mathrm{wt} \% \mathrm{Cl}$. The above suggest that water activity was probably less than unity, resulting in a shift of curves 5 and 6 in Fig. 4 towards lower temperatures.

Using the mineral assemblages observed we cannot perform rigorous calculations of metamorphic pressures. Orthogneisses from Proti village, Florina area, contain phengite with $\mathrm{Si}=6.6$ atoms p.f.u. in association with biotite, garnet, epidote, K-feldspar and albite, suggesting pressures of around $9 \mathrm{~kb}$ at temperatures of $570^{\circ} \mathrm{C}$.

\section{DISCUSSION AND CONCLUSIONS}

The present study has shown that pelitic protoliths from the Vernon Massif underwent pre-Alpine metamorphism at P-T conditions of $\sim 2.5 \mathrm{~kb} / 600-610^{\circ} \mathrm{C}$ in the western part, and $>4.5 \mathrm{~kb} />640^{\circ} \mathrm{C}$ in the northeastern part of the Massif respectively. In the western part of the Massif, metamorphism is associated with heat transport from deeper to shallower levels within the crust due to intrusion of granitoids plutons in a magmatic arc setting. Although a similar explanation could apply to the northeastern part of the Massif, it is more possible that the Sil-Bt gneisses constituted the basement into which the plutons have intruded. The preserved migmatite textures and muscovite pegmatites on the outcrop scale within the andalusite-cordierite schists support this point of view. The muscovite pegmatites are formed at $\mathrm{P}>3,5 \mathrm{Kbar}$, while the andalusite + cordierite at $\sim 2,5$ Kbar indicating a shallower level of the granitoid intrusion within host rocks suffered before the intrusion a high-T metamorphism. Alpine overprinting affected both pre-Alpine and Alpine protoliths, bringing about greenschist facies metamorphism in the western part and epidote-amphibolite/lower amphibolite facies metamorphism in the northeastern part of the Massif, both at pressures in the range 6-9 kb.

We are not aware of any existing radiometric data for the Alpine metamorphic event. Rb-Sr biotite ages of 52-56 Ma given by Koroneos (1991) and Katerinopoulos et al. (1992) for the E. Varnous pluton and its northward continuation into F.Y.R.O.M. (Baba pluton) respectively, reflect Alpine reheating and must be considered minimum ages since metamorphic temperatures were higher than the closing temperatures of $\mathrm{Rb}-\mathrm{Sr}$ in biotite. By contrast, in the W. Varnous pluton where Alpine metamorphic temperatures were $<350^{\circ} \mathrm{C}$, $\mathrm{Rb}-\mathrm{Sr}$ biotite ages (251-235 Ma) are not significantly different from igneous crystallization ages ( $300 \mathrm{Ma}$ ), thus suggesting only partial disturbance of the Rb-Sr isotopic system and, most importantly, emphasizing the pre-Alpine age of 
the low-P / high-T metamorphic event. Seidel et al. (1981), Altherr et al. (1994), and Langosch et al. (2000) have reported the occurrence of low-P / high-T metapelites similar to those described here, as tectonic blocks in the ophiolitic mulange of Crete and as klippen in the upper tectonic unit of the Cyclades. Based on K-Ar dating of metamorphic biotite, muscovite and hornblende and $\mathrm{Rb}$-Sr dating of magmatic biotite, the cooling ages of which vary between 75-66 Ma for Crete and 84-59 Ma for the Cyclades (see Langosch et al., 2000, and references therein), the above authors interpreted the low-P / high-T metamorphism and associated magmatism as having taken place during the Late Cretaceous. However, according to the petrographic descriptions of Seidel et al. (1981) and Langosch et al. (2000) it is clear that the low-P / high-T metamorphic rocks of Crete underwent low$\mathrm{T}$ overprinting. As a consequence of that the afore-mentioned ages on metamorphic and magmatic minerals should be viewed as cooling ages of an Alpine event, overprinting pre-Alpine lithologies of the Pelagonian nappe, which together with the overlying ophiolites have been thrusted onto the External Hellenides Zones. Aegean extension that commenced in Miocene and continues to the present time has dismembered the Pelagonian nappe; as a result, blocks of pre-Alpine rocks occur nowadays as much as $450 \mathrm{~km}$ apart.

Kilias and Mountrakis (1989) suggested that intrusion of Hercynian plutons such as those of Varnous-Kastoria caused contact metamorphic phenomena in the country rocks (metapelites) characterized by the development of sillimanite. This, in conjunction with the low metamorphic grade (lower greenschist facies) observed in the structurally underlying Permo-Triassic clastic sediments, led the above authors to the erroneous conclusion that metamorphism of the pluton country rocks at upper greenschist / lower amphibolite facies conditions took place before pluton intrusion. They have also claimed that contact metamorphism due to pluton emplacement explains the formation of migmatitic textures in certain metapelites. This, again, is incorrect, since there are migmatite outcrops of large areal extent that are spatially unrelated to pluton emplacement (e.g. E. Mt. Orthris, Pteleos and A. Dimitrios areas; S. Mt. Pelion, Platania area; N. Evia Island, Aedipsos-N. Porri area). In the A. Dimitrios and Aedipsos areas we have identified fibrous and prismatic sillimanite in grt-bt-sil metapelites, very similar to that described in this paper from E. Varnous (Perraki and Mposkos, unpublished data). Migmatites showing strong mylonitization at epidote-amphibolite facies conditions during the Early Cretaceous (Yarwood and Dixon, 1977) are known to occur in the Pieria Mts. area underneath granodioritic gneisses and TriassicJurassic marbles. Similar metamigmatites occur in the vicinity of Verdikoussa village and in the Sikourio area to the south of Mt. Ossa. The latter lie immediately over the Ambelakia blueschist unit.

We revise the lithological and structural stratigraphy of the Pelagonian nappe as it was originally presented by Kilias and Mountrakis (1989). Lithologies that were affected by a single metamorphic episode at upper greenschist/lower amphibolite facies conditions, such as those of the 'Klisoura Series' of Kilias and Mountrakis (1989) must be re-interpreted as belonging to the well-known Permo-Triassic volcano-sedimentary sequences of the western Pelagonian margin that display lower greenschist facies metamorphism.

\section{REFERENCES}

ALTHERR, R., KREUZER, H., LENZ, H., HARRE, W., AND DÜRR, S. 1994. Further evidence for a Late Cretaceous low-pressure/high temperature terrane in the Cyclades, Greece. Petrology and geochronology of crystalline rocks from the islands of Donoussa and Ikaria. Chem. Erde, 54, 310-328.

BERMAN, R.G. 1991. Thermobarometry using multiequilibrium calculations: a new technique with petrologic applications. Canadian Mineralogist, 29, 833-855.

BUCHER, K. N., AND FREY, M. 1994. Petrogenesis of metamoprhic rocks. Springer Verlag, Berlin. 318 pp.

KATERINOPOULOS, A., KYRIAKOPOULOS, K., DEL MORO, A., MITROPOULOS, P., AND GIANNOTI, U. 1992. Comparative study of Hercynian granitoids from NW Greece and S Yugoslavia. Chem. Erde, 52, 261-276.

KILIAS, A., AND MOUNTRAKIS, D. 1989. The pelagonian nappe. Tectonics, metamorphism and magmatism. Bull. Geol. Soc. Greece, 23/1, 29-46 (in Greek with English abstract).

KORONEOS, A. 1991. Mineralogy, petrology and geochemistry of the eastern Varnous pluton (NW Macedonia). Unpubl. PhD thesis, Univ. Thessaloniki, $271 \mathrm{pp}$.

LANGOSCH, A., SEIDEL, E., STOSCH, H. G., AND OKRUSCH, M. 2000. Intrusive rocks in the ophiolitic mélange of Crete - Witnesses to a Late Cretaceous thermal event of enigmatic geological position. Contrib. Mineral. Petrol., 139, 330-355.

LIPS, A. L. W., WIJBRANS, J. R., AND WHITE, S. H. 1999. New insights from ${ }^{40} \mathrm{Ar} /{ }^{39} \mathrm{Ar}$ laserprobe dating of white mica fabrics from the Pelion Massif, Pelagonian zone, internal Hellenides, Greece: Implications for the timing of metamorphic episodes and tectonic events in the Aegean region. In: Durand, B., Jolivet, L., Horvath, F., and Seranne, M., (eds). The Mediterranean basins: Tertiary extension within the Alpine Orogen. Geol. Soc. 
London, Sp. Publ., 156, 457-474.

MASSONNE, H. -J., AND SCHREYER, W. 1987. Phengite geobarometry based on the limiting assemblage with K-feldspar, phlogopite, and quartz. Contrib. Mineral. Petrol., 96, 212-224.

MOUNTRAKIS, D. 1983. The geological structure of the northern pelagonian zone and the geotectonic evolution of the internal Hellenides. Habilit. Thesis, Univ. Thessaloniki, 289 p. (in Greek with English summary).

MPOSKOS, E., AND PERRAKI, M. 2001. Alpine metamorphism of the pelagonian allochthon in the Kastania area (southern Vermion), (this volume).

SPEAR, F. S. 1995. Metamorphic phase equilibria and Pressure-Temperature-Time Paths. Min. Soc. Am., pp 799.

SEIDEL, E., OKRUSCH, M., KREUZER, H., RASCHKA, H., AND HARRE, W. 1981. Eo-Alpine metamorphism in the uppermost unit of the Cretan nappe system - petrology and geochronology. Part 2. Synopsis of high-temperature metamorphics and associated ophiolites. Contrib. Mineral. Petrol., 76, 351-361.

YARWOOD, G. A., AND DIXON, J. E. 1977. Lower Cretaceous and younger thrusting in the Pelagonian rocks of the High Pieria, Greece. $6^{\text {th }}$ Colloq. Aegean Region, Athens, v.1, 269-280. 